SHS Web of Conferences 6, 03007 (2014)

DOI: $10.1051 /$ shsconf / 20140603007

(C) Owned by the authors, published by EDP Sciences, 2014

\title{
Changes of Diet in Rural North China during the 60 Years since the Founding of the People's Republic of China
}

\section{-Based on the Case of Liangshan County of Shandong Province}

\author{
Dong Chuanling \\ Department of Social Sciences, Heze University, 274015 Heze Shandong, China
}

\begin{abstract}
People's diets have changed greatly in the rural north China during the 60 years since the founding of PRC, present the gradual characteristics obviously. In the previous 30 years, people almost continue the traditional way, and they had bland diet but just could barely feed themselves. In the leaner year, people had to allay their hunger with those which could be eaten. More unfortunately, they even had nothing to eat, and always died of cholera. In the later 30 years, their dietary changes speed up further, staple and non-staple foods were becoming more and more abundant, and people's life gradually improved, especially after implementation of the household contract responsibility system. The proportions of non-staple foods increase gradually, people have pursued not only nutrition, but also good health. They have increased their consumption of meat, eggs. What's more, security problem about food have aroused widespread concerns. Although their diets have become modern day by day but they have not given up the traditional diet. They began to emphasize the balance of refined food and grains, meats and vegetables, even the nutritional health. There were some new trends in consumer's needs, including the green consumption, healthy consumption, and civilized consumption.
\end{abstract}

Keywords. new China' sixty years; rural north China; Liangshan county; diet; change

\section{Introduction}

Food is the first element of human survival which is the most basic and the most important role in the human social life. Rites said: "The ritual at the beginning, start the diet". ${ }^{[1]}$ Marx once said: the people must put eating and living in the first, and then engaged in Politics, science, art, religion and so on. ${ }^{[2]}$ Diet has not only meted human survival need, but also to evolution in non-text, carrying the rich connotation in the form of social life, politics, economy, folk customs. We can understand the track and diet changes from the study, but also can be more profound understanding of the changes and development of social life. But there is lack of studies on it. This article based in Liang Shan County in Shan Dong province, using the theory of traditional and modern, continuous and fracture, and combining my own observation, experience and interviews. 


\section{The change of diet in North China countryside from the New China's publish to the collectivization}

From the New China's publish to the collectivization there is little change of diet in North China countryside. The diet mainly inherits the traditional forms which pay more attention to quantity, staple food and less attention to quality and non-staple food. Also there is more humid regimen than thick food in traditional diet. As the saying goes; bran can be the main food for half year. People in this age can only get warm and full through eating the delicate and rough food. In the disaster years, there could be no food to eat, so people had to full themselves by some food substitutes. Therefore, some people caught nutritional disasters such as edema disease just because of lack of nutrition.

\subsection{The rough diet in daily life}

Food can be divided into two grains: staple food and non-staple food. The staple food usually referred to cornmeal bens and meant they eat more comfortable. After 1949, the level of people's diet continued to improve, especially in about 1955, people's diet got great improvement. The custom of people's diet is inheritable and steady. People still adopted the traditional form of eating three meals a day, which was called "three meals a day". Influenced by the limit of production, people usually eat less in morning, dry in noon, and watery in night. People usually slept early in night, as well as lack of grain. Their dinner was watery and skimp. Usually the greeting words during dinner time was "have you eaten gruel?"

The staple foods that people eat in daily life are steamed corn bread or pie which was made of sorghum flour and potato flour. They didn't grudge to eating wheat flour and they only ate it when they got harvest and celebrated the Spring Festival. The best staple food during that period was steamed bread and roll which were made of wheat flour, sorghum flour and corn flour. People ate dry and fresh vegetables all year around. There was a saying in the local area: "When there are not enough dishes, add up the pickles." People ate just some vegetables which were available in the present season, such as cabbage, turnip, spinach and so on. People generally cooked the dish just by some condiments and salt. People merely ate meat except that in Spring Festival when the production team divided little meat. And they treat the guests just by some noodles. They didn't grudge to eating eggs, instead, they exchanged them for money. There was a saying during that time: "The staple food is potato and the bank is hen."

During that time, people drank the public well water. There were one or two well in every village. In the morning, people stood in line and carried their buckets to draw water. If they arrived late, the water lever was always low and they would return with an empty bucket. And there were dangerous factors of the well water that it could be polluted by pens and toilet stool. And the quality of well water was not good for people that it had high fluorine content which was harmful to people's health.

\subsection{Substitute food are eaten and People lack food during disaster years}

\subsubsection{Substitute food are eaten}

From the founding of new China to the period of collectivization, the problem of food shortages is serious. From the central to local people ate planning foods and saved foods.

In order to deal with food shortages, people had to eat wild vegetable at the beginning of the founding of new China. People even could not swallow the weeds but they have nothing to do.

The period of "Three years of difficult", people depended on the centrals' spirit of low standard. People save food and make full use of food substitutes. In 1960, people ate fresh cabbage, turnip, big beans, cowpea seeding, angle of leather, cotton shell and so on. ${ }^{[3]}$ After the three years of hard time, food also was hard to self-sufficiency and people still ate use substitute food. 
At the beginning of the founding of China, it happened frequently that people often lack food during disaster years. For example, food is serious lack after the flood in January 22 in 1950 in Liang Shan County. There are $24 \%$ of people were lacking food, some people died of hunger. 164 people died of hunger and disease until April 15 in 1950 in 5 District in Liang Shang County. ${ }^{[4]}$

Liang Shan County Rural had a serious lack of food from 1959 to 1961. People who were lacking food took $91.1 \%$ in Liang Shan County on March 19 in 1960. ${ }^{[5]}$ Because the human body's protein is not up to the minimum requirement, a lot of people suffered from edema disease. Many people die of hunger in Liang Shan County. The specific number of death was not accurate. According to the Liang Shan County Bureau, the county's population in 1957 was 419300, and in 1962 it deceased to 345900 , then it increased to 382500 in 1965 , and in 1970 it increased to 458200 .After about 10 years, the population of Liang Shan County was back to the levels in $1957 .{ }^{[6]}$ It can be obviously seen that the hanger disaster during the period of the three years severely influenced on the destruction of population in Liang Shan County.

\section{The change of diet since the implementation of household contract responsibility system}

People's diets have changed heavily after the institution of the household contract responsibility system. People's living standard is constantly improving. Non-staple food is increasingly rich in the countryside. People are not satisfied with eating and more pay attention to nutrition and healthy.

\subsection{Rich and nutrition diet in daily life}

Since the implementation of household contract responsibility system, the level of people's diet increases rapidly. Food is abundant and the proportion of the staple food in diet reduced. People's dietary structure is reasonable. At the same time, the staple food changes to refined grains. People diet gradually changed from extensive to nutritional. People pay more and more attention to the nutrition and healthy.

Life level is measured by the general standard of the quality and quantity of food. Since the implementation of household contract responsibility system, the vegetables are abundance and people gradually farewell vegetable shortage. Anti-season vegetables are enough all the year. People often say: "There is no food to eat in the past, now I don't know how to eat." The vegetables planting scale is increasing greatly. Nowadays, meat, eggs and milk have become an important part of People's Daily diet. Erie and other famous brand milk also are eaten by the ordinary people .Edible oil consumption is increasing. Fruit consumption becomes more and more big. The eating habits of people also quietly changed.

Drinking water becomes safety. In the $1980^{\prime}$ s, public Wells gradually were abandoned. The shallow groundwater is not safety. Therefore, governments at all levels attach great importance to it. People cannot drink bitter or salty water. Safety water project begins since 2005. By the end of 2007, water penetration rate has reached $95.87 \%$. ${ }^{[7]}$ The problem of rural difficulty of drinking water effectively solved. People had said goodbye to the history of the salty water.

\subsection{Simplified and nutrient diet}

People's diets have also changed heavily in Rural North China especially after the institution of the household contract responsibility system. The main and non-staple food is rich and all sorts of food are growing. Food has blurred the geographical concept, local and foreign, domestic and import, everything is sold in the market. Rural market growing rapidly and people almost every day go to the fair. Vegetables, meat, fruits, pastries etc. are plentiful. Everything fully meets people's dietary needs. Some vendors send vegetable, meat and pasta to the people directly to the door. Shop in the village 
has all kinds of food and vegetables. Meat has become important for farmer because they eat it everyday.

Convenience foods especially attract people attention. Quick-frozen dumplings are popular now in Rural North China. Less people steam bread and they directly go to the buns or purchase the coupon. Mechanical noodles gradually replaced hand rolling noodles. There are all kinds of cooked meat shop in the village and sell finished products or semi-finished products.

Kitchen gradually is gasification and electrification. Gas burner and microwave oven are common in the village. Soybean, milk machine, refrigerator and so on become the kitchen equipment. Cooking is convenient, fast and healthy.

People's diets have changed heavily in Rural North China after the institution of the household contract responsibility system. People pay attention to vegetable, nutrition and healthy. Food consumption "staple" turns into "non-staple" type. People's eating habit gradually turns "feast" into "nutrient". The pursuit of quantity needs to be developed for confrontation, tends to be green and healthy food. People like reasonable nutrition structure. Low fat, high protein diet, fine quality, low sugar, low salt, low calorie food is more and more popular.

People's diets are modern but the traditional diet is not break. People's traditional diet habit returns. After they fully enjoy refined grains and they realize the importance of coarse grains. Natural vegetables, vegetables, stupid chicken, green food are popular. Hand hammer, hand steamed bread is popular also. But the question of food safety becomes a hot topic of concern.

\section{The reasons and characteristics of the diet change in rural}

People's diets have also changed heavily in Rural North China during the 60 Years since the Founding of the People's Republic of China, especially after the institution of the household contract responsibility system. Its change affected by factors such as politics, economy and customs:

1) National policies and regulations. After the founding of new China, land reform is continuing and people share the land. People's enthusiasm of labor is improved. Agricultural production is increasing day by day. The level of people's diet is improving accordingly. Due to the limited market, low level of market after 1958, people's diets are limited by the government. People's food was allocated by production team. After reform and opening up in 1978, the western diet culture gradually came into north China rural. Agricultural production and farmers' income are increasing. People not only have enough food but pay attention to nutrition and healthy.

2) The level of economic development. At the beginning of the founding of new China, people's diet is limited. People's labor enthusiasm is not high in collectivization period and food production is low, less people has enough food and clothing in a year. After the implementation of household contract responsibility system, economic develops rapidly and agricultural production is increasing. At the same time, farmers' income is increasing. All kinds of food are enough and the level of people's diet gradually enhanced. Meat, eggs, milk, fruit and other food consumption are increasing. People pay more attention to nutrition and healthy than before.

3) Traditional diet custom. Because China has thousands years of traditional diet custom, its influence is deeply rooted. Western-style bread did not instead of steamed bread and a knife and fork also did not instead of chopsticks. The handing hammers and steamed bread and so on still loved by the people. The traditional three meals a day, the style of diet, dietary structure aren't lost. As a whole, people are not given up the old diet. The basic food structure will exist for a long period of time in the future. Traditional diet didn't split.

People's diets have also changed heavily in Rural North China during the 60 Years since the Founding of the People's Republic of China, especially after the institution of the household contract responsibility system. The characteristics of its change in Rural North China during the 60 Years since the Founding of the People's Republic of China mainly are these.

1) From poor to rich. Before the institution of the household contract responsibility system, people had a hard life without sufficient foods and they had bland diet but just could barely feed themselves. In the year of poor crop, people had to allay their hunger with those which could be eaten. More 
unfortunately, they even had nothing to keep off hunger, and always died of cholera. After that, staple and non-staple foods were becoming more and more abundant, and people's life gradually improved. They had a lot of feeding up with more and more non-staple food. The rural people who has pursued not only nutrition but also good health, has increased their consumption of meat, eggs and dairy products steadily.

2) From bland to nutrition. Before the implementation of household contract responsibility system, people's living level is low. They only have bland foods to eat when they have good harvest. Vegetable is main food for them which have single nutrients. Some people got dropsy and even starve to death in famine years. Since the institution of the household contract responsibility system, the level of people's diet increase rapidly, refined grains become staple foods. They not only have sufficient food to eat and meat, eggs, milk, fruit consumption is increasing. They pay attention to nutrition and healthy. People like low sugar or low salt food. Green food is popular.

3) From family to market. Before the implementation of household contract responsibility system, people income is limited and they rarely used to buy food. Most foods they eat are planted by themselves. Food and beverage industry get great progress along with the social economic rapid development after the Reform and opening up. Steamed bread, pastry, meat and pickles all are sold. There are all kinds of convenience food market in countryside. Even villages have most of the food in the market.

\section{Conclusion}

Great Changes of Diet have happened in Rural North China during the 60 Years since the Founding of the People's Republic of China. Diet of "staple" and bitter days has passed. People's living standard constantly improves and people's life gradually turned into well. Although the diet has changed greatly of the north China rural, but the traditional diet is continuing, isn't break.

\section{References}

1. Rites. Shenyang: Liaoning education press, 1997, p p.64-65.

2. Marx, Engels, Marx and Engels Anthology (volume 3). Beijing: People's publishing house, 1972, p.574.

3. The CPC Liangshan Commune Party Committees, About Allocation and Arrange Members Living Situation Report. Heze: Heze file collection 9-1-210, 1960-10-20, p.64.

4. The People's Government in Liangshan. Mass Life and Food-Deficit Number Statistics. Heze:Heze file collection 9-3-1, 1950-01-22,P31.

5. The People's Government in Liangshan, The Dead Inspection Report. Liangshan:Liangshan file collection 3-1-2, 1950-04-15, p.16.

6. The CCP Heze Prefectural Party Committee Office, Working Condition (issue 20). Heze: Heze file collection 9-3-53, 1960-03-09, p27.

7. Bureau of Statistics in Liangshan. Splendid Fifty Years: 1949-1999 (internal). Liangshan: Bureau of Statistics, 2000,p228. 